\title{
GONDOLATOK MESTER GYÖRGYI MESÉIRŐL
}

\section{A recenzió szerzője:}

H. Tóth István (Dr. CSc.)

Univerzita Karlova

(Csehország)

Szerző e-mail címe:

moszkva228@gmail.com

\section{Lektorok:}

Mező Ferenc (Ph.D)

Eszterházy Károly Egyetem

(Magyarország)

Mező Katalin (Ph.D)

Debreceni Egyetem

(Magyarország)

...és további két anonim lektor

H. Tóth István (2020): Gondolatok Mester Györgyi meséiről. OxIPO - interdiszciplináris tudományos folyóirat, 2020/4, 97-102. doi: 10.35405/OXIPO.2020.4.97
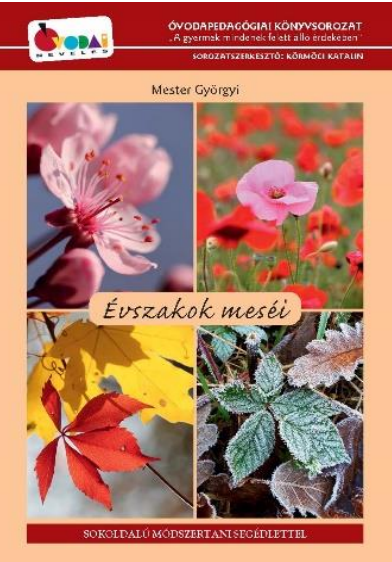

A recenzió alapjául szolgáló mü:

Mester Györgyi (2020): Évszakok meséi. Sprint Kft., Budapest. ISBN 9786158159500

Kulcsszavak: mese, óvodapedagógia

Diszciplína: pedagógia

\section{Bibliography of the subject of this recension:}

Mester Györgyi (2020): Seasons' Tale. Sprint Kft., Budapest. ISBN 9786158159500

Keywords: tale, kindergarden pedagogy

Discipline: pedagogy
Szakmai és pedagógiai érvekkel megtámogatottan ajánlom kisgyermekeknek, meserajongó nagyobbaknak, valamint óvodapedagógusoknak, tanítóknak és ma gyartanároknak is, továbbá a szülők népes táborának Mester Györgyi nemrég megjelent Évszakok meséi címü, 192 oldalas kötetét. 
Vállaltan és céltudatosan szubjektív ez a könyvismertetésem az Évszakok meséiről, tudniillik engem úgy beszippantott, magával ragadott ez a színpompás, költői, egyúttal a tudományos ismeretterjesztést mesei köntösbe ágyazott szövegvilág, hogy nem is kívánom az újdonságok iránt érdeklődők nyitottságát szűkíteni tudományos igényességű könyvbemutatással. Annál is inkább óvakodom ettől a megoldástól, mert nyilvánvalóvá tette Mester Györgyi jelen, 71 mesét tartalmazó könyvében, hogy a mesehallgató és a mesevilágot megismerni szándékozó gyermek szükségletei állnak az itt olvasható történetek középpontjában a környezetére mindinkább rácsodálkozó, az azt felfedező gyermekkel együtt. Ott állt a meséinek köszönhetően népszerű szerző, Mester Györgyi mellett szakmai társszerzőként Hornyán Anna, aki 58 oldalnyi tárgymutatót állított össze a kötet 71 meséjének a még sikeresebb felhasználását segítő szándékkal. Dicséretes Kónya Judit arculattervező tipográfiai munkája. Elismerésre méltó Keglovich Anita könyvborító fotója. Hálásak lehetünk mi, olvasók és felhasználók Keglovich T. Milán érzékeny, fantázianyitogató belső illusztrációiért.

Az Évszakok meséi címú könyv két részből áll. Az első rész a 10-138. oldalakon olvasható mesék körét öleli fel - ez Mester Györgyi ihletett, költői nyelvezetű, a kisebb és nagyobb gyermekek személyiségét gyarapító mesés történeteinek a gyűjteménye a négy évszak világába szőve, erős kitekintéssel az évszakok jeles napjaira és izgalmas, a gyermekeket helyzetbe hozó tevékenységlehetőségekre.

A kötet második része - ez Hornyán Anna mesterpedagógus szakszerű, kétségtelenül projektpedagógiai alapállású munkája, amely a 139-192. oldalakon fegyelmezetten sorakozó, ugyanakkor változatos szempontok figyelembevételével készített tárgymutatókat nyújt az itt olvasható mesék árnyalt, sokoldalú, változatos szemléletű felhasználását segítő szándékkal.

Ezek a szövegek - rövidebbek és hosszabbak egyaránt - közlő, tájékoztató és befolyásoló jellegűek, az érzelemviláguk rokon a potenciális mesehallgató és meseolvasó kisgyermekek lelkületével.

Ezek a mesés szövegek: legyenek klasszikus jegyekkel rendelkező mesék, mesenovellák vagy novellák, mind-mind érzékeny nyelvezetű, imponálóan gazdag szókincsű történetek. Bátran kijelenthető, hogy Mester Györgyi tudatában ott voltak a Vlagyimir Propp nevéhez kötődő mesei cselekvéselemek, és ezeket körültekintően, mindig a szükséges mértékben, helyénvalóan aktualizálta is. Így érhetők tetten a klasszikus mesei cselekvéssor: a hiány, az útnak indulás, az eltávozás, a próba, a tilalom, a tilalom megszegése, a varázseszköz, a kalauzolás, a cselvetés, a megbélyegzés, a kézre játszás, a küzdelem, a győzelem, a jutalom. Ha figyelmesen olvassuk ezt a most és itt általam csupán töredékesen felidézett cselekvéselemeket, akkor is látjuk, érezzük, hogy ezek bizony 
jelen vannak, illetőleg jelen lehetnek a világ valamennyi meséjében, így a magyar mesekincsben is. Ismét rögzítem: mindig az alaptörténet lényegéhez, a mesei jelleghez, a szereplők céljaihoz és világlátásukhoz illeszkedően, sohasem tolakodón vannak jelen az Évszakok meséiben, így bátran kijelenthetem, hogy a szerző sohasem öncélú megoldással alkalmazta a Propp által feltárt cselekvéselemeket. Ezért is szerethetők ezek a Mester Györgyimesék, mert természetesek, szinte hamvasok, és nyilvánvalóan lehetőséget kínálnak a mesehallgatónak, a meseolvasónak az identifikációra.

Pszichológiai tanulmányainkból tudható, hogy az identifikáció az azonosulás, másképpen: a modellkövetés magasabb szintje, amikor az empátia segítségével a mintának választott hős (szereplő) érzelmeit, hangulatait, a hőskép személyiségének értékeit, normáit, attitűdjeit veszi át a mesehallgató és/vagy a meseolvasó gyermek.

Amikor olvassuk és/vagy mondjuk (szájjal meséljük) majd óvodásainknak az Évszakok meséit, például az egérkirályról, a Sün Samuról és az elveszett tüskéről, a Pihécske kalandjairól, vagy a Sárkánykáról, a boldog hóemberről, a türelmetlen nyulacskáról, avagy a sárga kicsi kígyóról, a hímes récékről, a náthás méhecskéről, a szajkó fél pár papucsáról, a pillangófáról, illetőleg az aranygubóról, a Nóriról és a kenyérről, az aranykalászról szóló szövegeket, akkor rendkívül komoly, és a gyermekekkel való összehangolódásunkat erősítő megfigyelésekre tehetünk szert. Gondoljunk csak arra - egy-egy Mester Györgyi-mese szövegvilágában való elmélyedést követően -, hogy óvodásaink szerepjátékaiban, az egyes mesehallgató gyermekek mozdulataiban, beszédében, az egész viselkedésükben feltárul a maguk választotta hősképmodell hatása. Természetesen csoportbéli növendékeink nem pont olyanokká lesznek, mint a modell, hanem - és ez a csoda! - ők maguk a mintának tekintett (például Az egérkirály címú mese nyomán a cirmost hősképnek tekintő kisgyermek nem olyan, mint a cirmos, hanem ő maga a cirmos, azaz okos, megértő, türelmes, béketeremtő). Így épülnek be csoportunk kisgyermekeinek a személyiségstruktúráiba az egyes Mester Györgyi-féle mesehősmodellek viselkedései, gondolatai, sőt mondatai is.

Helyénvalónak tartom, hogy 71 meseszöveg került az Évszakok meséi kötetbe. Ez nem sok, nem kevés, hanem arányos. Amiként az is dicséretes, hogy a Tél és a Tavasz címú fejezetek tartalmaznak számosabb, azaz 26 és 25 mesét, mesenovellát és novellát. Az Ôsz 11, a Nyár fejezet 9 történetet kínál felolvasásra, szájjal mesélésre, illetőleg kisiskolásoknak önálló olvasásra. Ez a mesemennyiség arányosságra törekvő, vagyis figyelemmel van az óvodai nevelési-gondozási esztendő keretei biztosította játékközpontú tevékenységekre, a kisgyermekek szabad, részben szabad, illetőleg kötött játékaira a sok más óvodai tevékenység mellett. 
A Nyár fejezetnek azért is örvendek, mert a június eleji hőséghullám idején óvodásaink sem tavasz-, inkább nyárhangulatúak, amiként szeptember elején, a vénasszonyok idején sem az őszre figyelők, hanem a nyári kalandokat dajkálgató érzelemvilágúak. Vagyis a nevelési-gondozási év fináléja (zárása), illetőleg nyitánya (kezdete) idején lelkesen kalandozhatunk a Mester Györgyi-féle nyárvilágban.

Erősen feltételezem, hogy nem lesz gyakorló pedagógus, aki ne lelkesedne amiatt, hogy a 71 évszakmeséből 53 szöveg úgynevezett jeles naphoz kötődő mesés történet. Ezen jeles napokhoz mára számos vállalkozó és alkotó kedvű tehetséges óvodai szakember hasznosabbnál hasznosabb, jobbnál jobb tematikus szakanyagot szerkesztett, és ezek szemelvényanyaga most feldúsíthatóvá vált Mester Györgyi friss szemléletű, tanító jellegű mesés történeteivel.

Az Óvodapedagógiai Könyvsorozat jelen, XVI. kötete belső borítóin e könyv néhány meséjéhez készített 18 színes illusztrációval szembesülhetünk. Hogy soke, avagy kevés ezek száma, döntse el ki-ki maga. Nyelv- és irodalompedagógiai aspektusból, különösen a szemlélődő, hozzáadó, haszonelvű, a hasznosságra tekintő stratégia alapján magam úgy látom, hogy elégségesek ezek a belső borítókon látható színes és humoros képecskék, tudniillik motivációs bázisul is szolgálhatnak csoportunk alkotni vágyó mesehallgatóinak számos újabb és másféle technikájú, de a Mester Györgyi-mesék árnyalt illusztrá- cióinak az elkészitésére, valamint a róluk, ezáltal az itteni mesékről való beszélgetéshez.

Az Évszakok meséi kötet második részét Hornyán Anna óvodapedagógus mestertanár készítette el. A 139-192. oldalakon olyan tárgymutatókkal ismerkedhetünk meg, amelyek a mesék feldolgozását, megismerését előzetesen, vagy utólagosan, avagy közbe-közbe ékelődően is képesek megtámogatni. Kétségtelenül hasznos szakmai-pedagógiai meglátásokat ölelnek fel a betűrend szerinti tárgymutató, az úgynevezett módszertani tárgymutató, az évszakokhoz, a jeles napokhoz, a világnapokhoz, az ünnepekhez kapcsolódó, ugyanígy a múfajokra és a tartalmi választás megkönnyítésére tekintő, illetőleg a kisgyermekek életkorához kötődő tárgymutatók.

Nem vitás, hogy ez a kötetbéli mesék felhasználhatóságát támogató főfejezet a szakmai közösségeknek készült. Nagy hasznát vehetik az egyes csoportvezető óvodapedagógusok, amiként az óvodavezető szakemberek, valamint az óvodai szakmai munkaközösségek mind az egyéni, mind az intézményi tervező-szervező tevékenységek előkészítésekor, szervezésekor, tervezésekor.

Óvodapedagógiai kézikönyvként - megkockáztatom: főiskolai, illetőleg egyetemi hallgatói ajánlott, avagy kötelező szakirodalomként is - felhasználható maga a teljes Évszakok meséi könyv, vagy kiemelve ennek a 4. főfejezetét, mert az óvodai nyelvi, anyanyelvi és irodalmi ne- 
velés tervező, szervező tevékenységeinek az alaposabb megismerését, az így felgyűlt ismeretek sokoldalú, logikus, koherens rendszerezését, elemzését képes érzékenyen tanítani a pedagógusjelöltekkel.

Akik részben vagy egészében ismerik a dr. Hegedûs Gábor nevéhez füződő projektpedagógia mibenlétét, sőt részt is vettek az ennek a pedagógiai irányvonalnak a tanfolyamain, a múhelymunkáiban érdemi alkotó tevékenységeket is végeztek, minden bizonnyal felfedezik az Évszakok meséi című kötet tárgymutatóiban a példás, követendő elkötelezettséget az óvodapedagógiai projektek iránt.

A fentiek nyomán joggal merülhet fel a kérdés: ki is valójában Mester Györgyi? A választ fellelhetjük a világhálón elénk kerülő vonatkozó információkból. Ugyanakkor van egy másik, sokkal fontosabb, kétségtelenül ideillő kérdés: hogyan születtek meg ezek az évszakmesék, illetőleg az Évszakok meséi című kötet? Íme a legilletékesebb válasza!

\section{Mester Györgyi: Mesélek...}

„Hasznos elfoglaltságként, szórakoztató kikapcsolódásként kezdtem el írni, úgy tizenkét évvel ezelőtt. Mivel alapvetően novellista vagyok, eleinte kizárólag nagyon rövid, változatos: romantikus, realista, misztikus, kalandos, krimi műfajú, jellegú írásokkal foglalkoztam, ilyesmiket írtam.
Akkor ruccantam ki először a gyermekirodalom területére, amikor megszületett a három részből álló Zizi naplója című ifjúsági gyermeknaplóm. Ez még nem volt „igazi” mese, hiszen a naplóbejegyzésekben szereplő események akár a valóságban is megtörténhettek volna. Mégis, talán ez a könyvecském adta az indíttatást, hogy próbálkozzam meg mesék írásával is.

Erdő övezte településen élek. Sose felejtem el, amikor - buszon ülve, az ablakon át kitekintve - az erdő hatalmas, zöldben ragyogó fái között megpillantottam egy aprócska vadcseresznyefát, ami talpig virágban pompázott. Mintha hófehér lepkeraj telepedett volna a hajlékony ágacskákra...

Mese lett belőle, és A pillangófa címet kapta. Nem csak az egyik első mesém, de talán a legkedvesebb is. Megjegyzem, hogy négy idegen nyelvre is lefordították, és a Debreceni Egyetem egyik tanára szakmai jegyzetében - a fogalmazás, stílus és helyes nyelvhasználat tekintetében pozitív példaként említette, illetve több oldalon keresztül elemezte a szóban forgó mesém szövegét.

Nem sokkal később egy másik - A legkisebb cinke című - mesém meghódította az internetet. Jóleső érzés volt községi hírmondókban, egyházi lapokban, gyermekújságokban, blogokban, különböző honlapokon karácsonyi jókívánságok kíséretében viszont látnom ezt a kedves, gyermekeknek szánt történetemet. 
Később több karácsonyi mesét is írtam - általában nyáron. Hogy miért éppen akkor? Mert ráértem, és ötlet is akkor adódott. Viccesen, és persze nem kis büszkeséggel szoktam megemlíteni, hogy egy, az interneten talált karácsonyi mese-összeállításban a huszonnégy mese között öt Andersen és hat Mester Györgyi-mese szerepelt. Hát ennyit a népszerűségemrôl...

Bár a karácsonyi írásaim olvasottnak számítanak, mégis, mint a legelején már említettem, a legszívesebben állatokról és növényekről írok mesét. Kicsit úgy vagyok ezzel, hogy legyen egyszerü, kedves, közérthető, tanulságos a mese. Olyan, amit a kisgyerekek is megértenek, átélhetnek, adott esetben emlékeznek rá, és vissza is tudják mondani. Ha egy mese nagyon kacifántos, túl bonyolult a történetszövése, nem jegyzik meg, és akkor nincs is hatással a gyerekekre.

Az említett, állatokról és növényekről szóló meséimből néhányat elküldtem az Óvodai Nevelés című óvodapedagógiai, szakmai lap főszerkesztőjének is. $\mathrm{Az}$ írásaim tetszést arattak, ebből adódott, hogy felkérést kaptam a főszerkesztő aszszonytól egy mesegyújtemény összeállítására. Az írásokból kötet lett, amely 2020-ban Évszakok meséi címen jelent meg. Értékét főként az adja, hogy sokoldalú módszertani segédlettel egészítette ki Hornyán Anna, így az óvodapedagógusok munkájuk során jobban fel tudják használni.

Érzésem szerint a mai, modern világban nagy szükség van a mesékre, mert a gyerekeket leköti, és ha a történetek felkeltik az érdeklődésüket, azzal bővíthető a fantáziájuk, a szókincsük, gazdagítható az érzelemviláguk, és nem utolsósorban, megkedvelik az olvasást. És - a szórakoztatás mellett - ez az írásaim célja, lényege."

Adjon az Élet erőt, lelkesedést Mester Györgyinek, hogy egyértelműen sikeres legyen az Évszakok meséi című könyve a legszélesebb olvasói körökben! 